\title{
Application of RAPD Markers on Sex Determination of Papaya (Carica papaya)
}

\section{Aplikasi Marker RAPD dalam Seleksi Sex Tanaman Pepaya (Carica papaya)}

\author{
Riry Prihatini $^{1^{*}}$, Noflindawati ${ }^{1}$, Tri Budiyanti ${ }^{1}$ \\ ${ }^{1}$ Indonesian Tropical Fruit Research Institute, Jl. Raya Solok-Aripan km.8 Solok 27301, Sumatera Barat, Indonesia
}

Diterima 16 Januari 2019/Disetujui 25 Februari 2019

\begin{abstract}
Molecular sex determination of five varieties of Indonesian papaya were evaluated using RAPD (Random Amplified Polymorphism DNA) markers. Overall, 12 of 14 primers produced polymorphic bands on either several or all tested varieties. The OPC04 and RAPD2 markers could be used determined sex types on all varieties, whereas others primers are only on certain varieties. The Tangkai Ungu variety can be differentiate by markers OPA11, OPA14, OPC14, RAPD2, RAPD3, and RAPD5, the Lokal Sumani can be determine using markers OPA01, OPA11, OPA14, OPC01, OPC04, RAPD2, RAPD3, RAPD5, and RAPD6, the Merah Delima could be determined using OPC04, OPN09, RAPD2, and RAPD5, the Dampit could be determined using OPC01, OPC04, RAPD2, and RAPD6, whereas the Sicincing Panjang could be determined using OPA04, OPA11, OPA14, OPC04, RAPD2, and RAPD3. The OPC04 and RAPD2 could be used to determine sex types of the five papaya varieties tested.
\end{abstract}

Keywords: female, hermaprodhite, male, primer, plant

ABSTRAK

Evaluasi sex pada lima varietas tanaman pepaya Indonesia dapat dilakukan melalui identifikasi marka molekular RAPD (Random Amplified Polymorphism DNA). Pita polimorfik dapat terseparasi dengan baik pada 12 primer dari 14 primer yang digunakan. Primer OPC04 dan RAPD2 dapat membedakan tipe sex pada seluruh sampel tanaman yang digunakan. Varietas Tangkai Ungu dapat dibedakan dengan primer OPA11, OPA14, OPC14, RAPD2, RAPD3, dan RAPD5, varietas lokal Sumani dapat dibedakan pada primer OPA01, OPA11, OPA14, OPC01, OPC04, RAPD2, RAPD3, RAPD5, dan RAPD6. Varietas Merah Delima dapat dibedakan pada primer OPC04, OPN09, RAPD2, dan RAPD5, varietas Dampit oleh primer OPC01, OPC04, RAPD2, dan RAPD6, sedangkan varietas Sicincing Panjang dapat dibedakan oleh OPA04, OPA11, OPA14, OPC04, RAPD2, and RAPD3. Primer OPC04 dan RAPD2 dapat digunakan untuk membedakan tipe sex jantan, betina dan hermaprodit.

Kata kunci : betina, jantan, hermaprodhite, primer, tanaman

\section{INTRODUCTION}

Papaya (Carica papaya) is a trioecious plant with three sex types. Some papaya varieties are dioecious with female and male plants, whereas others are gynodioecious with female and hermaphrodite plants (Van Buren and Ming 2014). Sex identification on papaya is an important issue on the true hermaphrodite plants cultivation can be reduced the cost and increase profit.

Although the papaya flower morphology can easily identify, the seedling papaya sex determination is hardly to conduct. The PCR-based technique to verify papaya sex had been conducted using RAPD (Lemos et al., 2002, Urasaki et al., 2002, Gangopadhyay et al., 2007) and RAPD-SCAR

\footnotetext{
*Penulis untuk korespondensi. e-mail: riry_silva@yahoo.com
}

(Deputy et al., 2002, Chavez-Bedoya and Nunez, 2007, Shivkumar et al., 2014).

Indonesia is not the origin of the papaya but several varieties have superior characteristics, such as sweet taste, exotic color, and big size. Those varieties were planted for the commercial purposes, thus the seedling sex identification was crucial. The research was conducted to determine the seedling sex of papaya useing RAPD.

The aim is to find the accessions based on sex information to improve the agronomy traits. The commonly method to access plant genetic data is RAPD (Random Amplified Polymerase DNA). The reason used RAPD that are advantages in rapid, relatively easy and simple technique, can be operated in a undeveloped laboratory with minimum equipments. The result of RAPD analysis application in confirmation of genetic linkage and diversity (NejatzadehBarandozi et al., 2012), tolerant and quatitatives traits 
(Khaled et al., 2015), somaclonal variation (Dey et al., 2015, Stanisic et al., 2015), genotoxic effect (Aksakal et al., 2013), also sex determination in seedling (Vaidya and Naik, 2014).

\section{MATERIAL AND METHODE}

Five varieties of Indonesian papaya, namely Tangkai Ungu (hermaphrodite, female, and male plants), Lokal Sumani (hermaphrodite, female, and male plants), Merah Delima (female and male plants), Dampit (female and male plants), dan Sicincin Panjang (female and male plants) were evaluated. The DNA from leaves of the plants sample was extracted with method suggested by Doyle and Doyle (1986). The total of 14 primers used in this study. RAPD PCR reaction was performed with Taq $\mathrm{PCR}$ reaction mixture $4.25 \mu \mathrm{l}$ (KAPPA) with $1 \mu \mathrm{l}$ of RAPD, $1 \mu \mathrm{l}(10 \mathrm{ng})$ of sample DNA, and $\mathrm{ddH}_{2} \mathrm{O}$ to a final volume of $12.5 \mu \mathrm{l}$ reaction. PCR was performed by 45 cycles with the following programs pre denaturation $95{ }^{\circ} \mathrm{C}$ for 3 minutes, denaturation $95^{\circ} \mathrm{C}$ for 15 seconds, annealing $36^{\circ} \mathrm{C}$ for 15 seconds, extension $72{ }^{\circ} \mathrm{C}$ for 5 seconds, and final extension $72{ }^{\circ} \mathrm{C}$ for 10 minutes. The PCR formula and programs were optimized prior the real RAPD test to ensure the reproducibility of the test as suggested by Ghazi et al., (2013). The whole experiments were run in triplicate to check for the reproducibility.

DNA amplification product was separated by electrophoresis at $50 \mathrm{~V}$ for 20 minutes. The band pat terns were scored manually and automated using software BioDoc Analyzer. The Dice-Sorensen coefficient of similarity and the UPGMA method were used to construct the dendogram.
Relationship among the hybrids and parent were evaluated using Principal Co-ordinates Analysis based on Eigen value method. All of the calculation was conducted using the NTSYSpc 2.10x software (Rohlf, 2004).

\section{RESULT AND DISCUSSION}

The RAPD result of the sex determination of five papaya varieties was presented in Table 1. Overall, it was revealed that sex types of each varieties could be differentiate with different primers as shown by the polimorphic bands. The Tangkai Ungu could be determine by primer OPA11, OPA14, OPC4, RAPD2, RAPD3, and RAPD5, the Lokal Sumani with OPA11, OPC04, RAPD2, RAPD3, the Merah Delima with OPC04, OPN09, RAPD2, and RAPD5, the Dampit with OPC01, OPC04, RAPD2, and RAPD6, the Sicincing Panjang with OPA02, OPA11, OPA14, OPC04, RAPD2, and RAPD3. In addition, primers OPA01, OPY15, RAPD1, and RAPD4 produced monomorphic bands for all varieties and could not distinguish the sex type. On the other hand, primer OPC04 and RAPD2 produced polymorphic bands on all tested varieties thus could be used as papaya sex identification markers for the said varieties. The RAPD was chosen to asses the papaya genetic variability due to its simplicity, yet produce accurate result. Among the 30 RAPD primers tested, 14 primers result 119 bands, included 90 polymorphic bands (75.6\%). Each primer amplified 4-9 band with an average 8.5 band per primer and size of 2000$2200 \mathrm{~kb}$ size. Some representatives gel electrophoresis of papaya samples with some RAPD primers were performed in Figure 1.

Table 1. The RAPD result band pattern of five Indonesian papaya varieties.

\begin{tabular}{|c|c|c|c|c|c|}
\hline \multirow{2}{*}{ Primer (Sequences) } & \multicolumn{5}{|c|}{ Varieties } \\
\hline & Tangkai Ungu & Lokal Sumani & Merah Delima & Dampit & Sicincin Panjang \\
\hline OPA01 (CAGGCCCTTC) & $\mathrm{m}$ & $\mathrm{m}$ & $\mathrm{m}$ & $\mathrm{m}$ & $\mathrm{m}$ \\
\hline OPA02 (TGCCGAGCTG) & $\mathrm{m}$ & $\mathrm{m}$ & $\mathrm{m}$ & $\mathrm{m}$ & $\mathrm{p}$ \\
\hline OPA11 (CAATCGCCGT) & $\mathrm{p}$ & $\mathrm{p}$ & $\mathrm{m}$ & $\mathrm{m}$ & $\mathrm{p}$ \\
\hline OPA14 (TCTGTGCTGG) & $\mathrm{p}$ & $\mathrm{m}$ & $\mathrm{m}$ & $\mathrm{m}$ & $\mathrm{p}$ \\
\hline OPC01 (TTCGAGCCAG) & $\mathrm{m}$ & $\mathrm{m}$ & $\mathrm{m}$ & $\mathrm{p}$ & $\mathrm{m}$ \\
\hline OPC04 (CCGCATCTAC) & $\mathrm{p}$ & $\mathrm{p}$ & $\mathrm{p}$ & $\mathrm{p}$ & $\mathrm{p}$ \\
\hline OPN09 (TGCCGGCTTG) & $\mathrm{m}$ & $\mathrm{m}$ & $\mathrm{p}$ & $\mathrm{m}$ & $\mathrm{m}$ \\
\hline OPY15 (AGTCGCCCTT) & $\mathrm{m}$ & $\mathrm{m}$ & $\mathrm{m}$ & $\mathrm{m}$ & $\mathrm{m}$ \\
\hline RAPD1 (GCGGGTGGAA) & $\mathrm{m}$ & $\mathrm{m}$ & $\mathrm{m}$ & $\mathrm{m}$ & $\mathrm{m}$ \\
\hline RAPD2 (G TTTCGCTCC) & $\mathrm{p}$ & $\mathrm{p}$ & $\mathrm{p}$ & $\mathrm{p}$ & $\mathrm{p}$ \\
\hline RAPD3 (GTAGACCCT) & $\mathrm{p}$ & $\mathrm{p}$ & $\mathrm{m}$ & $\mathrm{m}$ & $\mathrm{p}$ \\
\hline RAPD4 (AAGAGCCCGT) & $\mathrm{m}$ & $\mathrm{m}$ & $\mathrm{m}$ & $\mathrm{m}$ & $\mathrm{m}$ \\
\hline RAPD5 (AACGCGCAAC) & $\mathrm{p}$ & $\mathrm{m}$ & $\mathrm{p}$ & $\mathrm{m}$ & $\mathrm{m}$ \\
\hline RAPD6 (CCCGTCAGCA) & $\mathrm{m}$ & $\mathrm{m}$ & $\mathrm{m}$ & $\mathrm{p}$ & $\mathrm{m}$ \\
\hline
\end{tabular}

Note $: \mathrm{m}=$ monomorphic, $\mathrm{p}=$ polymorphic 
The RAPD method had been used to differentiate sex types of Borassus flabellifer (George et al., 2007), Phoenix dactilyfera (Younis et al., 2008), Cammiphora wightii (Samantaray et al., 2010), Simmondsia chinensis (Hosseini et al., 2011), and Pistacia vera (Kamiab et al., 2014). The method had been proved to be a reliable strategy, as such markers for sex prediction can be analyzed at any developmental stage of growth (Agarwal et al., 2007).

The phylogenetics of all papaya varieties tested in this research was contructed to comfirm the result. The dendogram showed that the same varieties clustered in the same group (Fig. 2), thus the RAPD markers used differentiate the sex types and clustered the same varieties. The Tangkai
Ungu, Lokal Sumani, and Sicincin Panjang were Indonesian local varieties whith a unique characteristics, such as purple petiole and big size fruit. The Merah Delima and Dampit were hybrids with characteristics which meets the consumers choose, namely medium size and sweet taste. To our best knowledge, the molecular characteristics of these Indonesian varieties had not been explored before. Based on 0.76 Dice-Sorensen coefficient similarity the samples were clusted in five distinct group according to the varieties. With the unique purple petiole, the tangkai Ungu however was closely related to the Merah Delima compared to the other varieties. It could be implied that the two varieties might have the similar ancestor, yet the different evolution
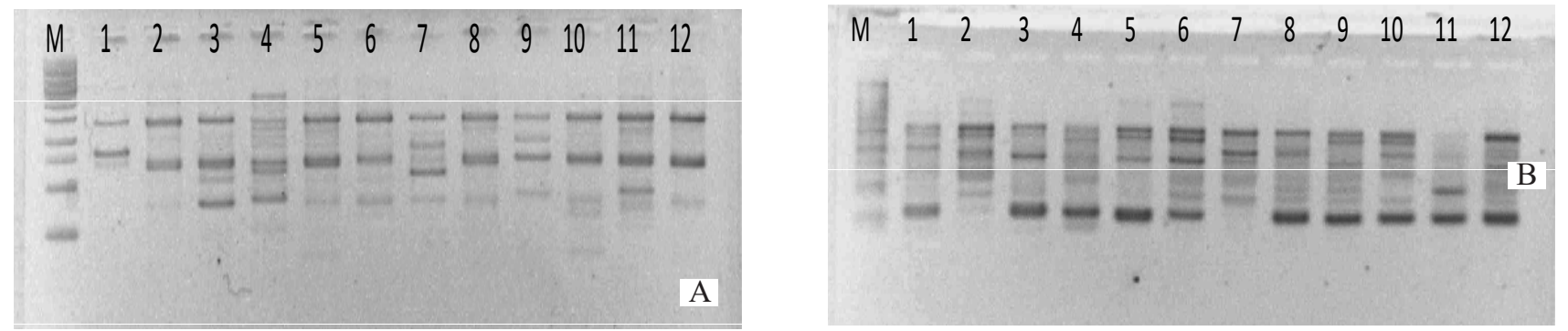

Figure 1. Band pattern of 5 papaya varieties using primer : OPC04 (A) and RAPD2 (B). M = 100 kb marker, $1=$ Hermaphrodite Tangkai Ungu, 2 = Female Tangkai Ungu, 3 = Male Tangkai Ungu, 4 = Hermaphrodite Lokal Sumani, $5=$ Female Lokal Sumani, $6=$ Male Lokal Sumani, 7 = Female Merah Delima, $8=$ Male Merah Delima, $9=$ Female Dampit, $10=$ Male Dampit, $11=$ Female Sicincin Panjang, 12 = Male Sicincin Panjang

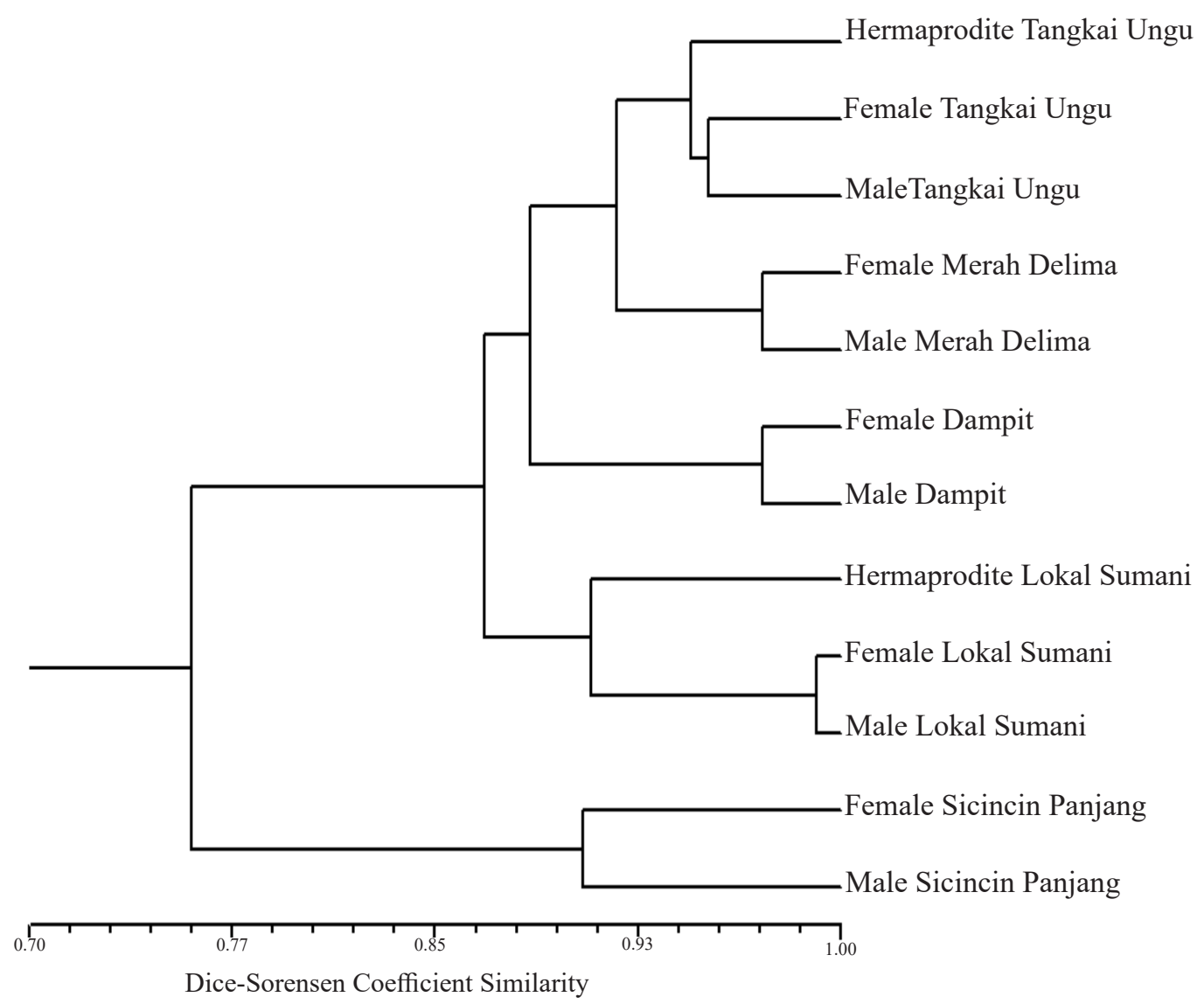

Figure 2. Dendogram of phylogenetics of five papaya varieties based on Dice-Sorensen Coefficient Similarity. 
pathway lead them to be different varieties. In addition, although the Lokal Sumani and the Sicincin Panjang shared the big fruit size characteristics, they had the furthest related to each other. The local varieties tend to self breeding, thus resulted offspring with more homozygos alleles and unique characteristics (Rodríguez-Burruezo et al., 2008).

\section{CONCLUSION}

The OPC04 and RAPD2 could be used to determine sex types of the five papaya varieties tested. Twelve out of 14 RAPD primers, also could be applied to resolve the tested papaya relationship. The OPA01 and RAPD5 produced monomorphic bands in all samples, thus should not be used for further papaya phylogenetics studies.

\section{ACKNOWLEDGMENT}

We would like to acknowledge Indonesian Tropical Fruit Research Institute, Indonesian Agency of Agriculture Research and Development for the funding of this research.

\section{REFERENCE}

Agarwal, V., K. Sharma., S. Gupta., R. Kumar, M. Prasad, 2007. Identification of sex in Simmondsia chinensis (Jojoba) using RAPD markers, Plant Biotechnol Rep (2007) 1:207-210.

Aksakal, O., F.G. Ertuk, S. Sunar, S. Bozari, G. Agar. 2013. Assessment of genotoxic effects of 2,4dichlorophenoxyacetic acid on maize by using RAPD analysis. Industrial Crops and Products 42: 552-557.

Chaves-Bedoya, G., V. Nunenz. 2007. A SCAR marker for the sex types determination in Colombian genotypes of Carica papaya. Euphytica 153:215-220.

Deputy, J.C., R. Ming, H. Ma, Z. Liu, M.M.M. Fitch, M. Wang, R. Manshardt, J.I. Stiler. 2002. Molecular markers for sex determination in papaya (Carica papaya L.) Theor. Appl. Genet 106: 107-111.

Dey, T., S. Saha S, P.D. Ghosh. 2015. Somaclonal variation among somatic embryo derived plants: Evaluation of agronomically important somaclones and detection of genetic changes by RAPD in Cymbopogon winterianus. South Afican J. of Botany 96: 112-121.

Doyle, J.J., J.L. Doyle. 1987. A rapid DNA isolation procedure for small quantities of fresh leaf tissue. Phytochemistry Bulletin 19: 11-15.

Gangopadhyay, G., S.K. Roy, K. Ghose, R. Poddar, T. Bandyopadhyay, D. Basu D, K.K. Mukherjee. 2007. Sex determination of Carica papaya and Cycas cirnicalis in pre-flowering stage by ISSR and RAPD. Current Science 92(4): 524-526.
George, J., A. Karun, R. Manimekalai, M.K. Rajesh, P. Remya. 2007. Identification of RAPD markers linked to sex determination in palmyrah (Borassus flabellifer L.). Current Science 92(8): 1075-1077.

Ghazi, F., Z. Benmechernene, M. Kihal, G.C. Gurakan. 2013. The reproducibility of random amplified polymorphic DNA (RAPD) profiles of Streptococcus thermophilus strains with XD9, M13, and MOD primers. African J. of Biotechnology 12(44): 6245-6252.

Hossaeni, F., S. Hassani, H. Shahsavand, M. Arvin, A. Baghizadeh, G. Mohammadi-Nejad. 2011. Sex determination of jojoba (Simmondsia chinensis cv. Arizona) by random amplified polymorphic DNA (RAPD) molecular markers. African J. of Biotechnology 10(4): 470-474.

Kamiab F., A. Ebadi, B. Panahi, A. Tajabadi. 2014. RAPD analysis for sex determination in Pistacia vera L. J. of Nuts 5(1): 51-55.

Khaled, A.G.A., M.H. Motawea, A.A. Said. 2013. Identification of ISSR and RAPD markers linked to yield traits in bread wheat under normal and drought conditions. J. of Genetic Engineering and Biotechnology 13: 243-252.

Lemos, E.G.M., C.L.S.P. Silva, A.H. Zaidan. 2002, Identification of sex in Carica papaya L. using RAPD markers. Euphytica 127: 179-184.

Nejatzadeh-Barandozi, F., M.R. Naghavi, S.T. Enferadi, A. Mousavi, Y. Mostofi, M.E. Hassani. 2012. Genetic diversity of accessions of Iranian Aloe vera based on horticultural traits and RAPD markers. Industrial Crops and Products 37: 347-351.

Shivkumar, P., Shamprasad P., Rohini B., Peter A. 2014, Molecular diversity analysis sex determination in papaya (Carica papaya L.) using molecular markers. The Bioscan 9(4): 1815-1820.

Stanisic, M., M. Raspor, S. Ninkovic, S. Milosevic, D. Calic, B. Bohanec, M. Trivfunovic, M. Petric, A. Subotic, S. Jevrimovic. 2015. Clonal fidelity of Iris sibirica plants regenerated by somatic embryogenesis and organogenesis in leaf-base culture-RAPD and flow cytometer analyses. South Afican J. of Botany 96: 42-52.

Urasaki, N., M. Tokumoto, K. Tarora, Y. Ban, T. Kayano, H. Tanaka, H. Oku, I. Chinen, R. Terauchi. 2002. A male and hermaphrodite specific RAPD marker for papaya (Carica papaya L.). Theory and Application Genetics 104:281-285. 
Vaidya, G., D.G.R. Naik. 2014. Molecular identification of sex in Simarouba glauca by RAPD markers for crop improvement strategies. Biotechnology Reports 4: 56-59.

Van Buren, R., R. Ming. 2014. Genomics of papaya sex chromosomes. In: Ming R., Moore P.H. (Eds.), Genetics and genomics of papaya, Plant Genetics and Genomics: Crops and Models, Springer Science-B usiness Media, New York: 309-326.

Rodriguea-Burruezo, A., J. Prohens, F. Nuez. 2008. Performance of hybrids between local varieties of eggplant (Solanum melongena) and its relation to the mean of parents and to morphological and genetic distances among parents. Europ.J.Hort.Sci., 73 (2): 76-83.

Rohlf, F.J. 2004. NTSYSpc: Numerical taxonomy and multivariate analysis sistem, ver 2.10x. Exeter Publishing Ltd., Setauket, NY.
Samantaray, S., K.A. Gheeta, K.P. Hidayath, S. Maiti. 2010. Identification of RAPD markers linked to sex determination in guggal (Commiphora wightii) Bhandari. Plant Biotechnology Report 4(1): 95-99.

Venkat, S., P. Bommisetty, M.S. Patil, L. Reddy, A. Chennareddy. 2014. The genetic linkage maps of Anthurium species based on RAPD, ISSR and SRAP markers. Scie. Hort. 178: 132-137.

Younis, R.A.A., O.M. Ismail, S.S. Soliman. 2008. Identification of sex-specific DNA markers for date palm (Phoenix dactylifera L.) using RAPD and ISSR techniques. Research J. of Agric. and Biol. Sci. 4(4): 278-284, 2008 